\title{
Five Times Daily
}

National Cancer Institute

\section{Source}

National Cancer Institute. Five Times Daily. NCI Thesaurus. Code C98849.

Five times per day. 